\title{
Mozambique: the panic and rage of the poor
}

\author{
Joseph Hanlon
}

Frightened poor people in Mozambique have killed Red Cross volunteers, a policemen, neighbours and strangers. In the first three months of 2009 , at least 20 people were killed in urban lynchings, three were killed for stealing rain, and 16 people died in violence related to cholera.

Key to all the incident is desperate poverty and hunger. For a decade Mozambique has been a donor darling for following the neo-liberal, free market development model, reporting GDP growth rates of 6-7 per cent per year, and claiming dramatic falls in poverty levels. But the claims of reducing poverty have been contested, in part because child malnutrition is rising. (Hanlon and Smart, 2008, ch 7, pp 57-70) 'The distance between rich and poor is widening', admitted the Mozambique self-evaluation submitted in February 2009 as part of the African Peer Review Mechanism evaluation of Mozambique. The statement is important, because until now the government and donors have stressed claims for poverty reduction and tried to refute evidence of deepening poverty. In an accompanying statement, Lourenço do Rosario, president of the National Peer Review Forum, warned that 'social exclusion and mal-distribution of wealth could constitute a space for conflict.' In fact, it is already happening.

In poor urban areas, people live in flimsy houses with no electricity or street lighting, and complain of increasing night-time crime, often by people armed with knives or machetes -- housebreaking, mugging, rape, and thefts of food from gardens. They claim that if they turn criminals in to the police, they are quickly released in exchange for a small bribe, so they have taken to dispensing justice with their own hands. In 2008 at least 50 people were killed in lynching, but in the first 10 weeks of 2009 the rate had doubled to two a week. (Notícias, 13 March 2009) The word 'linchar' has entered into Portuguese for executions by mobs, based on "lynch" in US English, used for mob killings, particularly of Black people in the US south in the 19th and 20th century. In Maputo, alleged criminals are killed by necklacing -- putting a tyre around their neck, filling it with petrol, and setting it alight -- a method used in South African townships in the 1980s against alleged apartheid spies.

The government's own statistics show urban poverty is increasing. Under the present economic model, the number of formal sector jobs is falling. Large demonstrations in Maputo on 5 February and then four other towns against the high cost of living shocked Mozambique. They were led by young people from the informal sector who organised by way to text message and blocked roads into and in the capital, closing Maputo. At least five people were killed and more than 100 injured, many shot by the police. Rogerio Sitoe, editor-in-chief of the government owned daily, Notícias, responded with a remarkable column, arguing that the root cause was 'the religious way we applaud and accept the prescriptions of the World Bank and International Monetary Fund', when these are really 'poison prescriptions'. They have destroyed jobs and failed to promote agricultural development, which has 'contributed greatly to the impoverishment of the countryside and forced a migration to the cities, particularly of the youth.' The government needs its own development policy and needs to stop treating World Bank and IMF statements as if they were 'bible verses'. A subsequent letter to the editor was published saying the demonstrations were not vandalism, but a strike by the people demanding their rights. And a columnist said the demonstrations were useful because before the riots, the elites simply did not understand the economic crisis was not just of the poor, but of the middle classes. (Notícias, 15, 18, 19 February 2008)

In a tour of Maputo poor neighbourhoods in mid-March 2009, first lady Maria da Luz Guebuza told young people they had to work harder to make their way in the informal sector. The state pays for teachers and education, she said; after that, it is up to young people themselves. But the young responded by saying that unless jobs were created or they were given help to be self-employed, crime would continue to increase. (Fauvet, 2009) 


\section{Rural hunger and cholera}

Meanwhile, the crisis is also growing in rural areas. In mid-March the government announced it had a surplus of 75,000 tonnes of maize, but admitted that marketing failures meant it did not reach areas of hunger. The poor do not have money to buy food, so private traders are not interested in going to remote areas.

In Nicoadala district in Zambezia province, local people are accusing the state of locking up the rain and only giving it to better off farmers. In mid-February three people were killed and six injured, accused of diverting the rain. One farmer was quoted by the Sunday newspaper Domingo as saying "In the farm over there, something is growing, but on mine, nothing. How is it that my neighbour can eat and I can't?"

Cholera is endemic in most of Mozambique, with 15,000 cases notified between the start of the most recent outbreak in October 2007 and early 2009. Of those, 170 people died - a mortality rate of $1.1 \%$, which is considered low, and results from an effective cholera identification and treatment programme. But over the past decade, anti-cholera programmes have been a source of much tension in coastal areas of northern Cabo Delgado and Nampula provinces.

On 6 January 2009 an angry mob burned down three cholera treatment tents that had been set up on the beach in Pemba, Cabo Delgado. The mob also attacked the houses of the neighbourhood secretary and his deputy, who were forced to flee to the police station. They were accused of allowing the tents, which they said spread the disease rather than treating it. Confusingly, in subsequent meetings people from the community accused the municipal authorities of doing nothing to stop the spread of cholera and of refusing to come to their community. On 18 January in Mecúfi, on the coast south of Pemba, and eight-person anti-cholera brigade was attacked and beaten again accused of spreading the disease.

Then in Quinga on the coast of Mogincual district in Nampula on 25 February 2009 two Red Cross volunteers who were part of a brigade publicising anti-cholera messages, which include putting chlorine in wells, were beaten to death, accused of poisoning the wells with cholera. Then three days later, in Angoche district (just south of Mogincual) protestors attacked health workers accused of spreading cholera. They were already being protected by the police so the mob attacked the police with knives and spears, disembowelling and killing a police sergeant and seriously injuring two other policemen. On the same day in Moma district (south of Angoche) a mob attacked a community leader accused of putting cholera in the wells; two policemen protecting him were hospitalised.

Protests against those accused of spreading cholera continued. In Quinga, three people were arrested but the crowd blocked the road to prevent them being taken out of the village; 37 Red Cross volunteers fled. On 18 March police arrested a number of people in Quinga and took them to Liupo, the Mogincual district capital. Liupo has no court, so they had to be held until they could be taken to Angoche to be tried and charged. The police were clearly frightened by what had been done to their colleagues in Moma and Angoche, so they pushed 48 people into the tiny single cell in Liupo police station. Thirteen people died of suffocation over night. (Three senior police officers from Liupo have been arrested.)

\section{Driven by fear}

Coastal Nampula province is one of the poorest areas of Mozambique. Mogincual was the centre of an outbreak of konzo (tropical ataxic neuropathy), an irreversible paralysis of the legs, in 1992-93, and cases have reported regularly since then. (Ernesto et al 2002) Cassava roots contain cyanogenic glucosides which can cause paralysis if eaten in quantity when the roots are not adequately processed; this occurs only in periods of severe hunger when there is little other food. In early 2009 it was reported that hunger was again sweeping the district due to a poor harvest caused by draught and cyclone Jokwe in 2008. The Mogincual district director of health said the return of konzo was 'inevitable'. (Noticias 27 February 2009). Fifteen schools in Quinga closed in the early 
March 2009 after 10,000 of the 12,000 enrolled primary school pupils abandoned classes, according to Mogincual Education Director Agostinho Mendes. He said their families were fleeing the area, mainly due to hunger but also because of the cholera and violence.

The Mozambican Red Cross (CVM) on 19 March said that in Quinga people attacked volunteers riding bicycles and wearing Red Cross T-shirts 'because they suspected they had money'. A house belonging to one of the murdered volunteers was burnt down, and two others were destroyed, the statement said. In addition, bicycles used by the volunteers were stolen, and some were destroyed. In Angoche, 13 houses of Red Cross volunteers were destroyed.

This is a repeat of similar incidents. In September 2006 a mob of 70 people armed with knives and machetes attacked an anti-cholera brigade of Save the Children, accusing them of putting cholera in the wells, in Nacala-a-Velha, again in coastal Nampula province. In December 2001 angry mobs in Nacala-a-Velha and neighbouring Memba district attacked anti-cholera teams, non-government organisations workers with bicycles and motorcycles, and police. Particularly notable was that they attacked traditional leaders (régulos, mapéwé) and local government officials. More than 100 houses were destroyed and at least one person killed.

The 2001 protests were studied by Carlos Serra, a sociologist from the Centre for African Studies of Universidade Eduardo Mondlane (UEM), Maputo, and a UEM team, and published in an excellent small book Cólera e catarse, (Serra, C 2003) which remains highly relevant to the present incident. Three obvious factors play a role. First the words 'cholera' and 'chlorine' are very close, in Portuguese as in English. For people who do not have a good understanding of disease mechanisms and only know that cholera comes from the water, the difference between putting cholera or chlorine in the water may not be clear. Second, when heath officials warn that cholera is coming, local people ask: How do they know? And the obvious answer is they must be bringing it. Third, this is a area of high tension between the governing Frelimo party and the opposition Renamo, which has some of its strongest support in northern coastal areas. This year's incidents come after a hard-fought local election in November in which the ruling Frelimo party won the three coastal cities of Nampula province, ousting incumbent Renamo mayors.

But the most important and shocking finding of the study was that poor people strongly believed that the rich and powerful wanted to kill them. In a climate of distrust and disempowerment, the poor responded violently against outsiders who they assumed were putting cholera in their water to eliminate them. In interviews in Memba, local people said that the two main NGOs there, SNV and Save the Children, had not done anything practical to help the people and had failed to carry out their promises. Similarly, local chiefs and governments officials were not seen to do anything useful for the people -- indeed, they were accused of accepting money from the outsiders who brought the cholera. This whole picture was reinforced when a health worker under attack took refuge in the local SNV office. (Serra, C 2003, pp 38-40)

The Serra study notes that protests were often led by unemployed youth who saw no future for themselves, and whose actions had the tacit backing of their elders. It became a protest against authority figures - regulos, government officials, and NGO workers, who were seen as distant, arrogant, and, most importantly, not delivering. The red motorcycles of SNV extentionists, driven dangerously and at high speed though villages, became a strong symbol of arrogance and distance.

And the events of 2001 have a number of more recent resonances. The 5 February 2008 riots in Maputo were led by semi-employed youth from the informal sector, who as in Memba had the implicit backing of their elders. And the Red Cross in their statement in March 2009 on Quinga highlighted the way the better off, senior figures or those with bicycles, were targeted. The local 'better off' in this area are still quite poor, but the hungry see them in league with outsiders who bring cholera.

In his blog, Carlos Serra (8 March 2009) recounts a story from Muidumbe district in Cabo Delgado. Between June 2002 and May 2003, 18 people were lynched -- accused of magically commanding seven lions who ate 46 local people. What he found interesting was that 'those accused of 
commanding the lions were all important people - the district administrator, chiefs, members of Frelimo, a local businessman, etc.'

Serra and his team concluded that the protests against chlorine in the water revealed 'a profound disquiet and lack of confidence in the state.' But the campaign against chlorine in the water was not a campaign against the state or against modernising, but rather just the opposite. It was a protest against a state which had become distanced from the people, which only appeared before elections, and which increasingly failed to provide services and a better standard of living. It was not against modernity, but against the failure to provide the fruits of development.

For Carlos Serra (10 March 2009), lynchings and the cholera and rain riots in the north are all "messages of protest" against insecurity and especially against growing social inequality. He argues that "these protests and demonstrations are products of insecurity, uneasiness, and social disequilibrium", being exercised in culturally ancient forms, expressed in terms of magic and witchcraft. They may seem incoherent, but that "hides a terribly coherent logic based around want." He stresses that despite the attacks on authority and state figures, it is really an appeal for help and for increased state support in these communities." And he predicts that there will be more events like the 5 February 2008 riots in Maputo against price rises.

\section{Modesty called for}

Finally, some modesty is called for on our part. We 'know' that chlorine in water helps to prevent the spread of cholera, and thus will 'know' that local people were wrong in their belief that putting chlorine in the water was a cause of cholera. But how different is the cholera debate in Nampula from the HIV/AIDS debate in South Africa, in which the President himself, one of the world's most respected leaders, questioned the wisdom and understanding of the some of the world's most eminent scientists? Or consider the donors, IMF and World Bank who imposed the neo-liberal model and accused those of use who disagreed of being as 'stupid' as the peasants opposed to chlorine in water - only to discover after 20 years that neo-liberalism brought a world economic crisis instead of development.

Objections to chlorine may be scientifically unfounded, but reflect a well-founded social and political understanding. If a nurse or health post worker normally demands a bribe to provide proper treatment, why should they be trusted when they say they are giving chlorine free? If an arrogant NGO helps only a select few, why should it suddenly be trusted to help the poorest on a key health issue? If government actions have only led to increasing poverty and loss of jobs, why trust the government now? And if local chiefs and party secretaries have used their links with the outside to collect taxes and increase their own power, why should they be trusted to help now? The poor have every reason to ask if the sincere priests and health workers and NGO staff sent into rural areas are not just an attempt to build up trust so that the poor can be better exploited. And they have every reason to distrust the local leaders who ally themselves with the new outside exploiters.

In a time of hunger when people see no hope of improvement in their lives, perhaps the passive and violent resistance to putting chlorine in local water supplies should be seen as local people making a desperate attempt to regain some power; as a disempowered group finally taking a stand to defend its very lives.

Joseph Hanlon is senior lecturer in development and conflict resolution at the International Development Centre, Open University, Milton Keynes, England. He is the editor of an irregular newsletter on Mozambique, available free from http://tinyurl.com/mz-en-sub

\section{References}

Ernesto, Mario et al (2002): 'Persistent konzo and cyanogen toxicity from cassava in northern Mozambique', Acta Tropica, 82(3), pp357-363.

Fauvet, Paul (2009), 'Youth urged to work hard to develop the country', AIM Mozambique News Agency, Maputo, 17 March 2009. 
Hanlon, Joseph \& Smart, Teresa (2008), Do Bicycles Equal Development in Mozambique?, James Currey, Woodbridge, Suffolk, UK, ISBN: 978-1-84701-319-4

Serra, Carlos (2003) Cólera e catarse. Imprensa Universitária, Universidade Eduardo Mondlane, Maptuo. (The full book, in Portuguese, is posted on: http://www.tinyurl.com/mozamb. A preface, by Joseph Hanlon, in English and Portuguese, is included.)

Websites for ongoing coverage of these events:

Carlos Serra: http:www.oficinadesociologia.blogspot.com Joseph Hanlon: http://www.tinyurl.com/mozamb Notícias: http://www.jornalnoticias.co.mz

26 March 2009 